\title{
1 Expanding fish productivity in Tasmanian saltmarsh wetlands \\ through tidal re-connection and habitat repair
}

Vishnu Prahalad $^{\mathrm{AC}}$, Violet Harrison-Day ${ }^{\mathrm{A}}$, Peter McQuillan $^{\mathrm{A}}$ and Colin Creighton $^{\mathrm{B}}$

${ }^{\text {A }}$ Geography and Spatial Sciences, School of Technology, Environments and Design, University of Tasmania, Hobart 7001, Australia

B TropWATER, James Cook University, Townsville, Queensland, Australia

${ }^{\mathrm{C}}$ Corresponding author. E-mail: vishnu.prahalad@utas.edu.au

\section{Abstract}

Fish use of coastal saltmarsh wetlands has been documented for many parts of Australia with the notable exception of Tasmania. An initial investigation to examine the diversity, density and patterns of fish use in the Circular Head coast saltmarshes of north-west Tasmania was undertaken. To aid decision making in repair strategies, the effect of saltmarsh condition on fish assemblages was studied using paired sites of predominantly unaltered and altered saltmarshes where levees were present. A total of 851 fish from 11 species were caught in 37 of the 48 pop nets. Three species, Aldrichetta forsteri, Arripis truttaceous and Rhombosolea tapirina, are important to commercial and recreational fisheries and contributed about $20 \%$ of the total catch numbers. The mean density of $>72$ fish per $100 \mathrm{~m}^{2}$ is the highest yet reported from Australian studies and indicates that Tasmanian saltmarshes provide higher value habitat for fish compared to elsewhere in Australia, likely due to more frequent and prolonged flooding together with the lack of adjacent mangroves. There was no significant difference in fish assemblages between unaltered and altered marshes. The results suggest that restoring basic saltmarsh structure through tidal re-connection will deliver substantial benefits for fish productivity through habitat expansion.

Additional key words: biodiversity, coastal management, ecological restoration, ecosystem services, seascapes, salt marsh, temperate fish communities, wetland conservation

Running head: Repairing saltmarsh wetlands for fish use 


\section{Introduction}

Saltmarsh wetlands are well recognised as fish nurseries globally, with a growing literature documenting the importance of these habitats for itinerant fish use (e.g. Connolly 2009; Raposa and Talley 2012). The general expectation is that saltmarshes, and their associated tidal channels, provide both secure and productive habitat and food resources. For example, Kneib (1997), Deegan et al. (2000) and Valiela et al. (2000) detail how fish utilise these seascapes at varying spatial and temporal scales. In Australia, there is now an increasing number of studies to support this expectation, with accounts of fish visiting and feeding in saltmarshes (Crinall and Hindell 2004; Hollingsworth and Connolly 2006; Mazumder et al. 2006a; Platell and Freewater 2009; Mazumder et al. 2011; McPhee et al. 2015). As elsewhere, Australian saltmarshes have also been documented to export food resources (plant and animal matter) to coastal waters through tides, thereby improving overall seascape productivity (Melville and Connolly 2003; Svensson et al. 2007).

While more research is being undertaken in Australia, the majority of research on saltmarsh fish has been focused elsewhere, particularly in North America. A review by Connolly (1999) indicates that, of literature published before $2000,90 \%$ of studies were from North America, 7\% from Europe and 3\% from the southern hemisphere including Australia (although additional work has since been published). Contrasts exist in habitat type between Australian and North American saltmarshes, including differences in typical elevation, water depth and plant assemblages (Connolly 2009), making comparisons problematic between international studies. Australian studies have primarily been undertaken in tropical, subtropical and temperate waters in Queensland, New South Wales, Victoria and South Australia (Davis 1988; Connolly et al. 1997; Thomas and Connolly 2001; Crinall and Hindell 2004; Mazumder et al. 2006b).

Australian literature reporting on the fish use of temperate saltmarshes record up to 35 species with densities of up to 56 fish per $100 \mathrm{~m}^{-2}$ (Connolly 2009; Wegscheidl et al. 2017). In terms of patterns of fish use, spatial and temporal differences between regions are apparent, including varying effects of seasonality, tide cycle, water depth, diel time, temperature and salinity on fish assemblages (Morton et al. 1987; Davis 1988; Connolly et al. 1997; Thomas and Connolly 2001; Crinall and Hindell 2004; Mazumder et al. 2005a). Although a major focus of North American research has explored differences in fish use between varying saltmarsh conditions (e.g. Raposa and Talley 2012), there are few comparable studies from Australia (Connolly 2005; Mazumder et al. 2006b). There still remains a lack of directed studies relating saltmarsh condition to fish assemblages in Australia (Connolly 1999; Kelleway et al. 2017).

To our knowledge, and certainly in the scientific literature, there have been no prior studies of fish use of Tasmanian coastal saltmarshes, with no previous record of fish species diversity, density, patterns of use and preference between varying habitat conditions. As both saltmarshes and mangroves have been found to host many fish species (Mazumder et al. 2005a; Saintilan et al. 2007), and given the absence of mangroves in Tasmania, measuring the diversity, density and patterns of fish use of saltmarshes (where no adjoining mangrove habitat is present) is important. As well as the absence of mangroves, Tasmania's saltmarshes differ in their seascape context to those found in mainland Australia. In comparison, Tasmanian saltmarshes are situated 
slightly lower on the tidal frame (thus being subject to a different flooding regime) and contain different vegetation assemblages compared to many of their mainland counterparts (Boon et al. 2015; Saintilan et al. 2009; Mount et al. 2010).

An understanding of fish use is particularly important where saltmarshes have declined most rapidly due to tidal restriction as part of agricultural development, as in the Circular Head coast saltmarshes of north-west Tasmania (Prahalad 2014). These low lying agricultural areas that are affected by salinization and flooding could easily be repaired in terms of tidal ventilation. The benefits of re-connecting tidal flows in the form of increased fish production through expanded habitat would potentially offset any loss in agricultural outputs, as well as provide additional ecosystem services (Creighton et al. 2015; Kelleway et al. 2017; Wegscheidl et al. 2017). Saltmarsh rehabilitation would also assist in building resilience to climate change and relative sea level rise (Prahalad et al. 2015).

The following questions underpinned our Circular Head study: (1) what is the diversity and density of fish in the saltmarshes? (2) are there any observable patterns of fish use relative to location, tide cycle, water depth, diel time, temperature and salinity? (3) is there differences in fish use between saltmarshes of varying condition? (4) what are the implications for biodiversity repair and coastal management, and what additional research and on-ground activities might be required? In addressing these questions, the study also explored whether Tasmanian saltmarshes supported different assemblages and densities of fish taxa compared to lower latitude Australian sites.

\section{Materials and methods}

\section{Study area}

The Circular Head coastal area is located in the far north-west of Tasmania, between Woolnorth Point and the small town of Stanley (Fig. 1). The area is well sheltered from the high-energy wave climate of Bass Strait and contains an expansive seascape matrix of tidal flats, seagrass beds, saltmarshes and Melaleuca ericifolia swamp forests on the landward margin (Mount et al. 2010; Prahalad et al. 2015). The saltmarshes in the Circular Head coastal area occupy 1326 ha, as part of 23 distinct clusters associated with creek/river mouths, embayments, sheltered passages or tidal islands, and account for nearly a quarter of all saltmarsh mapped across Tasmania (Prahalad 2016). The area has a semi-diurnal tidal cycle with a mesotidal range of up to $3.1 \mathrm{~m}$, the largest on the Tasmanian coast (Donaldson et al. 2012). Within the tidal frame, saltmarshes occur over a $0.5 \mathrm{~m}$ range in elevation and are flooded partially during neap tides and almost fully during high spring tides (Mount et al. 2010). The low marsh is characterised by succulent mats of Sarcocornia quinqueflora often cooccurring with Samolus repens, and about 10-20 cm high (when flooded). The high marsh and back marsh areas are dominated by the succulent shrub Tecticornia arbuscula often mixed with halophilic grasses and sedges, about $50-150 \mathrm{~cm}$ high.

\section{Fig. 1}

M. ericifolia swamp forests dominate the landward margins of the tidal frame occupying the low lying coastal floodplain areas and competing with saltmarsh at the upper limits of the tidal extent. A large part of the swamp forests and the adjoining saltmarsh has, however, been cleared and drained for agricultural purposes, with over 

levee building was observed from old aerial imagery dating from the late 1960s, while the most extensive period of clearing and draining was during the 1980s. The estimated absolute loss of saltmarsh between 1952 and 2006 is 219 ha (16\%), with 752 ha $(65 \%)$ of the remaining saltmarshes subject to impacts including clearing, drainage ditching, cattle grazing and buffer zone removal (Prahalad 2014). Levee and 2016 (unpublished data). The Circular Head coastal area has been specifically selected for this study for having the largest extent of saltmarsh with rehabilitation potential in the State. The area is also of considerable importance to commercial and recreational fishers (Mount et al. 2010). There are also oyster farms in the area which depend on good water quality as part of a healthy seascape.

\section{Sampling methods}

Methods used to sample fish in saltmarshes include fyke nets, seine nets, pop nets, lift nets, block nets, flume nets, flume weir, drop samplers, traps, dip nets and hand trawls, and also poisoning (Connolly 1999, 2009). Of these, pop nets are now used in Australia more than other techniques (e.g. Connolly 2005; Mazumder et al. 2005b; Saintilan et al. 2007), as they are easily portable for sampling replications and provide a density measure (fish per $\mathrm{m}^{-2}$ ) that is directly comparable to other studies (Wegscheidl et al. 2017). Although studies have used different pop net types and sampling regimes, the general tendency has been to use a larger sample area $\left(\sim 25 \mathrm{~m}^{-2}\right)$ to avoid small scale patchiness, with a fine mesh size $(\sim 2 \mathrm{~mm})$ to catch juvenile fish and a remotely controlled release. In this study, we employed four custom made buoyant floorless pop nets, each covering an area of $25 \mathrm{~m}^{-2}$ (with $5 \mathrm{~m}$ long x $1 \mathrm{~m}$ high walls) and with a mesh size of $2 \mathrm{~mm}$. The bottom of the net walls contained a leadcore rope that was tucked under the saltmarsh substrate and pegged down by 10-12 weed mat pins on each side. This helped avoid excessive soil disturbance (cf. Connolly 2005). The top of the net walls contained a sleeve suitable for a $20 \mathrm{~mm}$ PVC pipe that was inserted in-situ and sealed for floatation. The net was neatly folded under the PVC pipe so that the installation sat flat on the marsh surface as much as possible. Weights were placed on the PVC pipe to keep it from floating with the incoming tide until the nets were ready to be popped. The installation was completed during low tide and took about 60 mins per net with two people working in tandem.

The four nets were used concurrently at the nearby paired sites of unaltered and altered saltmarshes, located in Robbins Passage, Big Bay and Perkins Passage (see Fig. 1). The three locations were $2.5-10 \mathrm{~km}$ apart from each other and selected on the basis of being representative of the saltmarshes of the Circular Head coast. Unaltered saltmarshes had no hydrological alterations due to levees and other human impacts (such as drainage ditches, clearing, grazing), were surrounded by a contiguous native buffer vegetation zone, and were relatively unfragmented being part of a larger saltmarsh cluster. Altered marshes had significant hydrological alterations due to levees and other human impacts (such as drainage ditches, clearing, grazing), had a little to no native buffer vegetation being juxtaposed to agricultural land used largely for cattle grazing, and belonged to highly fragmented saltmarsh clusters of variable size (Table 1.).

\section{Table 1.}




\section{Sampling procedure}

188 At slack high tide, the fully installed nets were released remotely (10-15 m) by two field personnel pulling the strings connected to the weights at the same time. The nets popped instantaneously ( $\sim 1$ second) and were then surveyed for entrapped fish, mostly at the downstream side(s) into which they were channelled as the tide receded. Fish were collected at regular intervals using hand-held dip nets to mitigate loss due to predation by birds and crabs inside the net. Some of the larger and more active crabs were evicted from the nets to prevent predation on fish when the water levels were low. Depending on the tide height, it took between 1-2 hrs for the flood tide to recede fully from the marsh surface. A thorough final inspection was made before concluding each sampling effort by checking all four walls and tiny depressions inside the net for camouflaged species. Collected fish were identified in the field, recorded and released. A few representative samples of each species were taken to confirm field identification by fish experts (following Gomon et al. 2008). These fish were terminally anesthetised in the field using a lethal dose of AQUI-S ${ }^{\circledR}$, a commercially available derivative of clove oil. Specimens were preserved immediately into a solution of $95 \%$ ethanol. Size range measurements of the fish from both the preserved samples and photographic evidence collected during field work helped in inferring the likely age of the fish.

Fish were sampled from four nets concurrently released in both unaltered and altered sites, at two replicate nets per site. The replicates were located randomly on the marsh flats and spaced no further than $25 \mathrm{~m}$ apart (cf. Thomas and Connolly 2001). Sampling was conducted during both high tides (night and day) of the semi-diurnal tidal cycle. The same procedure was repeated on successive days at the three study locations, yielding 24 samples during the neap tide cycle in April 2017. Sampling effort was doubled to 48 net releases in the following spring tide cycle in May 2017 following the same procedure. The neap tidal cycle samples were located near the seaward edge of the marsh expecting lower water levels and the spring tidal cycle samples were located slightly higher on the marsh platform expecting higher water levels (with distance to seaward edge proportional to the paired unaltered and altered marshes). Water temperature, salinity and time of net release (diel time) were recorded at each sampling location on all 12 sampling occasions. Water depth was recorded at each net as the mean of maximum and minimum depth, as the marsh surface was sloped.

\section{Data analysis}

Summary statistics were used to gain an overall impression of the fish community. To gauge the completeness of the sampling, a species accumulation curve (collector's curve) was produced using specaccum in the vegan library (Oksanen et al. 2011). Samples taken when the maximum water depth was less than $5 \mathrm{~cm}$ (mean water depth $<3 \mathrm{~cm}$ ) were excluded from further analysis as they yielded no fish due to lack of access. To explore the relationship between the environmental variables and fish species abundance within the overall assemblage, we related four response variables fish species richness per sample, fish catch per sample and the abundance of the two most common species - using generalised linear models (GLMs) to a suite of predictor environmental variables - location, condition status, tide cycle (spring vs neap), diel phase (night vs day), water salinity and mean water depth. Since the response variables were based on count data, Poisson or quasi-Poisson models with a log link function were applied as appropriate. We used a Wilcoxon Rank Sum test to 
explore for differences in total catch between diel phase, tide cycle and saltmarsh condition.

The multiple response permutation procedure (MRPP) in vegan was used to test for assemblages. The Bray-Curtis dissimilarity measure and 999 permutations were employed. The MRPP statistic delta is the overall weighted mean of within-group means of the pairwise dissimilarities among the sampling units. $A$ is a chancecorrected estimate of the proportion of the distances explained by group identity, a value analogous to a coefficient of determination in a linear model (Oksanen et al. 2011). The degree to which the fish assemblages varied between unaltered and altered sites was assessed using nMDS ordination based on the Bray-Curtis dissimilarity measure (Clarke and Warwick 2001). Fish counts were not transformed since the range of values was not extreme. The stress level of 0.1909 in 2 dimensions was acceptable (Quinn and Keogh 2002). Analyses were carried out in the R statistical environment (R Foundation for Statistical Computing, Vienna, Austria).

\section{Results}

A total of 851 fish of 11 species from 8 families were caught (Table 2.). All the individuals caught were either juveniles or sub-adults. The species accumulation curve (Fig. 2) estimates a total of 12 species and suggests the number of samples collected was satisfactory to reveal most of the fish taxa present at the sites.

The profile of the saltmarsh fish fauna reflected strong differences in the relative abundance of particular species (Fig. 3). The family Atherinidae contributed 3 species and $74 \%$ of the total catch numbers, of which Atherinosoma microstoma and Leptatherina presbyteroides were most abundant (57\% and $16 \%$ respectively). Two members of the family Gobiidae, Pseudogobius sp. and Nesogobius maccullochi, contributed $3 \%$ and $2 \%$ of the total respectively. Three species, Aldrichetta forsteri (Mugilidae), Arripis truttaceous (Arripidae) and Rhombosolea tapirina (Pleuronectidae) are of direct commercial and recreational value (Lyle et al. 2014). These fishery valued species contributed about $20 \%$ of the total catch. A. forsteri was both common and dominant, present in $24(65 \%)$ of the 37 nets that caught fish and made up $19 \%$ of the total catch. Palaemonid shrimps (Palaemon sp.) were observed in most of the nets, sometimes in large numbers ( 200) but not censused as the study was restricted to finfish. Crabs were also observed in all of the nets and have been inventoried for the Circular Head saltmarshes by Richardson et al. (1997).

\section{Table 2.}

\section{Fig. 2.}

\section{Fig. 3.}

The pop nets were very effective at catching fish with 37 of the 48 net releases returning between 3 and 69 fish per net. One of the nets failed in the Robbins Passage unaltered saltmarsh during the neap tide night-time sample. The mean density of fish caught with the exception of one net that failed to set properly was 72.4 fish per 100 $\mathrm{m}^{-2}$ (Table 2.). Because the maximum water depth was less than $5 \mathrm{~cm}$ (average water depth $<3 \mathrm{~cm}$ ) on 5 occasions where the high tide mark did not fully extend to the area 
covered by the nets our sampling of population density is probably an under-estimate. addition, it is likely that Gobiidae were probably undersampled on occasions where they were hiding in crab holes well after the marsh flat had drained after the spring high tide. Mugilidae may also have been undersampled given their ability to jump, however, our regular sampling regime would have mitigated against this risk. We conclude the mean density of fish caught to be $>72$ fish per $100 \mathrm{~m}^{-2}$.

The mean catch and species richness \pm SE per net/sample was $18.11 \pm 2.58$ individual fish and $2.60 \pm 0.22$ taxa respectively. Both the catch $(\mathrm{r}=0.6113, p<0.01)$ and species richness $(r=0.5131, p<0.01)$ were positively correlated with mean water depth. However, there was no correlation between water salinity and either catch $(\mathrm{r}=$ $0.0842, p>0.05)$ or species richness $(r=-0.0249, p>0.05)$. The range in salinity level was modest across the samples (33.1 to $36.6 \mathrm{ppt}$ ). Temperature ranged from 9 to $18.9^{\circ} \mathrm{C}$ (mean of $14.4{ }^{\circ} \mathrm{C}$ ), however this was not a significant variable. Only two of the environmental variables were significant in the generalised linear models (Table 3). Fewer fish and slightly lower species richness were apparent in the daylight sampling compared to night-time of the diel phase. Similarly, mean water depth had a strong positive effect on all four response variables. Notably, A. microstoma was caught in greater numbers in night-time samples $(p<0.001)$, while A. forsteri catch was slightly higher at night-time $(p<0.05)$, both species responding positively to water depth $(p<0.001)$. The effect of location was only noticeable in the case of $A$. forsteri with marginally greater numbers recorded at Perkins Passage $(p<0.10)$.

The Wilcoxon test confirmed that total catch per sample was related to the diel phase ( $\mathrm{W}=296, \mathrm{p}=0.001)$. However, although more fish were caught during the spring tide cycle $(\mathrm{n}=526)$ than neap tide $(\mathrm{n}=325)$, tide cycle $(\mathrm{W}=169, \mathrm{p}=0.215)$ was not a significant factor on total catch per sample. Similarly, more fish were caught in altered sites $(n=493)$ compared to unaltered sites $(n=358)$, yet saltmarsh condition $(\mathrm{W}=260, \mathrm{p}=0.319)$ did not significantly affect total catch per sample. Water depth was able to better explain catch numbers for both spring and neap tide cycles and for altered and unaltered sites examined separately (Fig. 4a-b).

\section{Table 3.}

\section{Fig. 4a-b.}

MRPP showed there was no significant difference between the unaltered and altered sites based upon their fish assemblages (chance corrected within-group agreement $A=$ -0.0120 , based on observed delta $=0.6353$ and expected delta $=0.6278$, the significance of delta $=0.917$ ). Ordination results further confirmed that there were no discernible differences in the fish assemblages between unaltered and altered sites (Fig. 5).

Fig. 5 .

\section{Discussion}

Fish species composition and density 
As the initial study of fish assemblages of Tasmanian saltmarshes it provides an excellent baseline for further investigations. The species encountered in this study largely overlap with those reported from other temperate Australian saltmarshes (Connolly 2009). The fish assemblage is dominated by species from the families Atherinidae, Gobiidae and Mugilidae. Of the other common fish families reported in temperate Victorian (Crinall and Hindell 2004) and New South Wales saltmarshes (Mazumder et al. 2005a, Mazumder et al. 2006b), Ambassidae, Gerridae and Sparidae were absent because their geographic range does not extend to Tasmania. Local species of the families Sillaginidae and Tetraodontidae were also not encountered in our study, although, the tetraodontid Tetractenos glaber (Smooth Toadfish), was observed adjacent to the nets both in Robbins Passage and Big Bay. Notably, our study provided a rare record in Australian saltmarshes of a member of the commercially and recreationally valuable family Arripidae. The two other species of commercial and recreational value, A. forsteri and $R$. tapirina, are also found in other temperate Australian saltmarshes. The relative abundance of $A$. forsteri in our total catch (19\%) is, however, comparatively much higher for a member of the Mugilidae (cf. 2-6\% of total catch by Crinall and Hindell 2004 using fyke nets in Victoria, and by Mazumder et al. 2005a, 2005b using pop nets and Mazumder et al. $2006 \mathrm{~b}$ using fyke nets in New South Wales). The variable sizes $(\sim 4-20 \mathrm{~cm}$ total length) of individuals caught suggest this abundance is not related to life history phases based on inferred age (Chubb et al. 1981).

In terms of species richness, the 11 species recorded in our single season of sampling compares well with other temperate Australian studies. Reports range from 10 species collected from fyke nets in Victoria (Crinall and Hindell 2004) to 14-15 species collected from pop nets in New South Wales (Mazumder et al. 2005a, 2005b; Saintilan et al. 2007). Comparable pop net studies from Queensland have reported 2319 species (Thomas and Connolly 2001; Connolly 2005), indicating a latitudinal trend in diversity of saltmarsh fish along the east coast of Australia (Table 4.). Another latitudinal trend is the marked change in A. microstoma as the most numerically dominant species in higher temperate latitudes in Tasmania (present study), Victoria (Crinall and Hindell 2004) and South Australia (Bloomfield and Gillanders 2005), to the ambassid Ambassis jacksoniensis (Port Jackson Glassfish), in lower temperate latitudes in New South Wales (Mazumder et al. 2005a, 2005b; Platell and Freewater 2009). The similarity in the relative abundance of these two species at different latitudes indicates an equivalence of ecosystem structure whereby functionally related species perform comparable roles. The minor component of Gobiidae and Mugilidae is also reflected in other studies.

Our reported density of $>72$ fish per $100 \mathrm{~m}^{-2}$ is higher than from other Australian saltmarshes, including subtropical locations (Table 4.). This could be a seasonal outcome where sampling in autumn returned high fish catches, although there is little evidence for significant seasonal variations in fish on temperate saltmarshes in Australia. Mazumder et al. (2005a) showed seasonal variation in fish abundance in mangroves near Sydney, peaking in summer, but not in the case of the adjoining saltmarshes. Bloomfield and Gillanders (2005) also reported no significant differences in fish richness and abundance in saltmarshes from South Australia between months. A more plausible explanation for the high fish density reported in this study could be the unique position of Tasmanian coastal saltmarshes as part of seascapes where mangroves are absent. Consequently, Tasmanian saltmarshes occur 
slightly lower on the tidal frame. In our study area with a mesotidal range, saltmarshes are partially flooded even during neap tides unlike most mainland Australian counterparts which only flood in spring tides (Bloomfield and Gillanders 2005; Connolly 2009). Saltmarshes of Tasmania would seem to provide a higher habitat value for fish per hectare, due to longer availability of flooded habitat together with the lack of any complementary habitat such as mangroves.

\section{Table 4.}

\section{Patterns of fish use and implications for tidal restoration}

It is well documented that coastal saltmarsh rehabilitation through restoring tidal flows ensures benefits for fish through expanded habitat (Roman et al. 2002; Raposa and Talley 2012). Our study reinforces this expectation, firstly through the strong effect that water depth has on fish density and richness found in this and some other studies (Thomas and Connolly 2001; Connolly 2005). When tide-restricted areas are open to flooding, they can accommodate the spread of a given volume of water (entering the embayment or sheltered passage) over a greater surface area. Tidal restoration, therefore, opens up more shallow, sheltered environments, rich in food sources, preferred by juvenile and sub-adult fish species (e.g. A. forsteri and Mugil cephalus, Sea Mullet: Chubb et al. 1981). Secondly, there was only a minor effect of the sampling location on both fish richness and density. Given that the study area has in excess of $25 \mathrm{~km}$ of levees traversing multiple freehold properties, coastal rehabilitation works could be initiated wherever site specific opportunities arise with likely benefits for local fish productivity through expanded habitat. While the saltmarsh area already lost to clearing was 221 ha, a further 629 ha (55\% of current extent) is affected by impaired tidal flows (Prahalad 2014). These areas can benefit from simple on ground works (e.g. levee breaching) aimed at tidal restoration.

In a broader seascape context, an ongoing debate on fisheries centres on the relative importance of different habitat types, including saltmarshes, to the marine food web (Kelleway et al. 2017). Only a few Australian studies have simultaneously compared saltmarsh with other nearby habitats (mangroves, seagrass and unvegetated/open water) with respect to fish use. Bloomfield and Gillanders (2005) noted that saltmarsh had the least number of fish (a solitary A. microstoma for a saltmarsh area of $270 \mathrm{~m}^{-}$ ${ }^{2}$ ), compared to mangroves, seagrass and unvegetated habitats of a South Australian estuary. Similarly, Saintilan et al. (2007) reported fewer fish in a New South Wales saltmarsh compared to adjacent mangrove and seagrass. The latter study however showed that fish moved between these habitats and that saltmarsh plays both a complementary role in terms of additional food resource and also a refuge role for smaller fish during spring tides (when the seagrass habitat is 'exposed' to larger predatory fish). Mazumder et al. (2005a) also reported more fish in mangroves bordering saltmarsh in the same New South Wales location, although, acknowledged that fish density was higher in the saltmarsh when corrected for water volume. A common emphasis of these and some overseas studies (e.g. Valiela et al. 2000), has been on the role of a permeable seascape matrix of adjacent habitats for fish to access at varying timescales. The value of saltmarsh for fish and the marine food web is very likely higher in the Tasmanian context because of the absence of mangroves.

\section{Difference in fish use between unaltered and altered saltmarshes}


This study is also the first in Australia to document differences in fish use between paired unaltered and altered saltmarshes (Connolly 1999, 2009). Our findings indicate that altered marshes can support high densities of fish and of comparable species richness to unaltered marshes. One of the known reasons for high fish numbers in our altered marshes could be due to the greater marsh to edge ratio, a product of habitat fragmentation, allowing greater access to fish (Minello et al. 1994). A more substantive reason, however, could be just that altered marshes can provide similar habitat functions for fish use if they are subject to a natural tidal regime comparable to its unaltered counterparts. There is considerable evidence, such as from temperate North America, of restoring saltmarshes having similar fish habitat value to reference sites (Raposa and Talley 2012). Further, re-connection of tide-restricted marshes has been shown to return fish richness and density to levels comparable to unaltered ones within one year (Roman et al. 2002). Indeed, our spring tide samples from altered sites in Robbins Passage and Perkins Passage were both located immediately behind the breached levees, and still returned high fish density and species richness. It must be noted though that these altered sites had a similar tidal regime, vegetation and crustacean activity to their paired unaltered sites (an indication of some functional equivalence). A comparative study of three saltmarshes of the Sydney region indicated that one of the marshes reclaimed from dredge spoil had significantly lower diversity and abundance of fish, possibly due to lack of functional equivalence (Mazumder et al. 2006b). The contrasting results from these two studies indicate an unexplored threshold effect in saltmarsh condition, likely context specific (e.g. with and without fringing mangroves), which can help explain relative fish habitat value and guide tidal restoration efforts.

\section{Implications for coastal management}

The priority for management must be the conservation of existing saltmarshes and their tidal connectivity (e.g. Boon et al. 2015). The Boullanger Bay and Robbins Passage areas which are least affected by levees and associated clearing and drainage ditching activities (see Fig. 1 and Prahalad 2014) are particularly significant. Targeted tidal restoration can be undertaken in Big Bay, Perkins Passage, and other nearby areas of Duck Bay and West Inlet. In addition, rehabilitation of the buffering $M$. ericifolia swamp forests could benefit the broader functioning of the local seascape, through enhanced detrital pathways (e.g. Svensson et al. 2007), or reduced nutrient stress on the seascape from the nearby beef and dairy farms (Holz 2009).

Rehabilitation of saltmarsh and adjacent swamp forests would also assist in mitigating the effects of climate change and relative sea level rise already affecting the Circular Head coastal area (Prahalad et al. 2015). Science communication is also essential. Public understanding of both the high fish density and species richness in the saltmarsh and of the links to commercial and recreational fisheries, including oyster farming, would increase broad community motivation for seascape conservation and repair (Creighton et al. 2015). North-west Tasmania is renowned for its popular fishing culture, and this may well be an important and locally unexploited avenue for stakeholder engagement in tidal restoration and coastal management (Wegscheidl et al. 2017).

\section{Conclusion}


This study reveals a hitherto unrecognised aspect of Tasmanian saltmarshes and provides a foundation for further research coupled with rehabilitation efforts. Clearly Tasmanian saltmarshes are important for our coastal biodiversity, providing nursery grounds and key food chain elements to Tasmania's coastal fisheries. Sampling across the year and similar surveys of other sites would expand our knowledge substantially. Our expectation is that such studies would reinforce and possibly increase the fisheries and marine biodiversity values of these coastal wetland systems. From a repair perspective, this study also provides evidence that re-connecting tidal flows and re-establishing wetland function and vegetation would deliver benefits to coastal fisheries. Re-connecting tidal flows to marshes isolated by levees would markedly expand the habitat suitable for fish use. This is despite the historically 'altered' condition due to tidal isolation, clearing, drainage ditching and rough grazing. Should Tasmania seek to optimise ecosystems services, marine biodiversity, fisheries productivity and flow on economic outcomes then a major program of saltmarsh repair should be initiated. Fish remain a compelling subject with broad resonance and can be used as a surrogate for the broader values of ecosystem services that these seascapes provide. Additional studies to document fish use of saltmarshes and the benefits of protection and repair could raise much needed public awareness and material support for saltmarsh repair.

\section{Conflict of interest}

This manuscript is an edited version of the same study available in a report form (see Creighton et al. 2017).

\section{Acknowledgements}

Laura Van Galen, Zhi Loh, Alistair Deane and Larissa Giddings provided assistance with fieldwork. Jeremy Ward and the Circular Head Landcare Group also assisted with fieldwork. Debashish Mazumder (ANSTO) assisted with sampling methods. John Pogonoski (CSIRO) provided fish identification guidance. Protocols included approval (ref: A16284) from UTAS Animal Ethics Committee and permit (no: 17012) from Wild Fisheries Management Branch of Tasmanian Government. Funding was provided by the Australian Government's National Environmental Science Programme: Marine Biodiversity Hub and Australian Government Research Training Program (RTP) Scholarship. Three reviewers provided valuable comments.

\section{References}

Bloomfield, A. L., and Gillanders, B. M. (2005). Fish and invertebrate assemblages in seagrass, mangrove, saltmarsh, and nonvegetated habitats. Estuaries 28, 63-77.

Boon, P. I., Allen, T., Carr, G., Frood, D., Harty, C., McMahon, A., Mathews, S., Rosengren, N., Sinclair, S., White, M. \& Yugovic, J. (2015). Coastal wetlands of Victoria, south-eastern Australia: providing the inventory and condition information needed for their effective management and conservation. Aquatic Conservation: Marine and Freshwater Ecosystems 25, 454-479. 
530 Clarke, K. R., and Warwick, R. M. (2001). 'Change in Marine Communities: an 531 Approach to Statistical Analysis and Interpretation.' 2nd Edn. (Plymouth Marine

Chubb, C. F., Potter, I. C., Grant, C. J., Lenanton, L. C. J., and Wallace, J. (1981). Age structure, growth rates and movements of sea mullet, Mugil cephalus L., and yellow-eye mullet, Aldrichetta forsteri (Valenciennes), in the Swan-Avon River system, Western Australia. Australian Journal of Marine and Freshwater Research 32, 605-628.

Connolly, R. M. (1999). Saltmarsh as habitat for fish and nektonic crustaceans: challenges in sampling designs and methods. Australian Journal of Ecology 24, 422430.

Connolly, R. M. (2005). Modification of saltmarsh for mosquito control in Australia alters habitat use by nekton. Wetlands Ecology and Management 13, 149-161.

Connolly, R. M. (2009). Fish on Australian saltmarshes. In 'Australian Saltmarsh Ecology’. (Eds N. Saintilan.) pp. 131-148. (CSIRO Publishing: Melbourne).

Connolly, R. M., Dalton, A., and Bass, D. A. (1997). Fish use in of an inundated saltmarsh flat in a temperate Australian estuary. Australian Journal of Ecology 22, 222-226.

Creighton, C., Boon, P., Brookes, J., and Sheaves, M. (2015). Repairing Australia's estuaries for improved fisheries production: What benefits, at what cost? Journal of Marine and Freshwater Research 66, 493-507.

Creighton, C., Walshe, T., McLeod, I., Prahalad, V., Sheaves, M., and Taylor, M., (2017). Repairing and conserving Australia's saltmarshes and seascapes. Centre for Tropical Water \& Aquatic Ecosystem Research (TropWATER) Publication, James Cook University, Townsville.

Crinall, S. M., and Hindell, J. S. (2004). Assessing the use of saltmarsh flats by fish in a temperate Australian embayment. Estuaries 27, 728-739.

Davis, T. L. O. (1988). Temporal changes in the fish fauna entering a tidal swamp system in tropical Australia. Environmental Biology of Fishes 21, 161-172.

Deegan, L. A., Hughes, J. E., and Rountree, R. A. (2000). Salt marsh ecosystem support of marine transient species. In 'Concepts and Controversies in Tidal Marsh Ecology’. (Eds M. P. Weinstein and D. A. Kreeger.) pp. 333-365. (Kluwer: Dordrecht, the Netherlands.)

Donaldson, P., Sharples, C., and Anders, R. J. (2012). The tidal characteristics and shallow-marine seagrass sedimentology of Robbins Passage and Boullanger Bay, far northwest Tasmania. Report to Cradle Coast Natural Resource Management Region. School of Geography and Environmental Studies, University of Tasmania, Hobart. 
Gomon, D. M. F., Bray, D. J., and Kuiter, R. H. (2008). 'Fishes of Australia's southern coast.' (Reed New Holland: Sydney, NSW, Australia..)

Hollingsworth, A., and Connolly, R. M. (2006). Feeding by fish visiting inundated subtropical saltmarsh. Journal of Experimental Marine Biology and Ecology 336, 8889.

Holz, G. K. (2009). Seasonal variation in groundwater levels and quality under intensively drained and grazed pastures in the Montagu catchment, N. W. Tasmania. Agricultural Water Management 96, 255-266.

Kelleway, J. J., Cavanaugh, K., Rogers, K., Feller, I. C., Ens, E., Doughty, C., and Saintilan, N. (2017). Review of the ecosystem service implications of mangrove encroachment into salt marshes. Global Change Biology 23, 3967-3983.

Kneib, R. T. (1997). The role of tidal marshes in the ecology of estuarine nekton. Oceanography and Marine Biology Annual Review 35, 163-220.

Lyle, J. M., Stark, K. E., and Tracey, S. R. (2014). 2012-13 Survey of Recreational Fishing in Tasmania. Institute for Marine and Antarctic Studies, University of Tasmania, Hobart.

Mazumder, D., Saintilan, N., and Williams, R. J. (2005a). Temporal variations in fish catch using pop nets in mangrove and saltmarsh flats at Towra Point, NSW, Australia. Wetlands Ecology and Management 13, 457-467.

Mazumder, D., Saintilan, N., and Williams, R. J. (2005b). Comparisons of fish catches using fyke nets and buoyant pop nets in a vegetated shallow water saltmarsh flat at Towra Point, NSW. Wetlands (Australia) 23, 37-46.

Mazumder, D., Saintilan, N., and Williams, R. J. (2006a). Trophic relationships between itinerant fish and crab larvae in a temperate Australian saltmarsh. Marine and Freshwater Research 57, 193-199.

Mazumder, D., Saintilan, N., and Williams, R. J. (2006b). Fish assemblages in three tidal saltmarsh and mangrove flats in temperate NSW, Australia: a comparison based on species diversity and abundance. Wetlands Ecology and Management 14, 201-209.

Mazumder, D., Saintilan, N., Williams, R. J., and Szymczak, R. (2011). Trophic importance of a temperate intertidal wetland to resident and itinerant taxa: evidence from multiple stable isotope analyses. Marine and Freshwater Research 62, 11-19.

Melville, A. J., and Connolly, R. M. (2003). Spatial analysis of stable isotope data to determine primary sources of nutrition for fish. Oecologia 136, 499.

McPhee, J. J., Platell, M. E., and Schreider, M. J. (2015). Trophic relay and prey switching-A stomach contents and calorimetric investigation of an ambassid fish and their saltmarsh prey. Estuarine, Coastal and Shelf Science 167, 67-74. 
Minello, T. J., Zimmerman, R. J., and Medina, R. (1994). The importance of edge for natant macrofauna in a created salt marsh. Wetlands 14, 184-198.

Morton, R.M., Pollock, B. R., and Beumer, J. P. (1987). The occurrence and diet of fishes in a tidal inlet to a saltmarsh in southern Moreton Bay, Queensland. Australian Journal of Ecology 12, 217-237.

Mount, R. E., Prahalad, V., Sharples, C., Tilden, J., Morrison, B., Lacey, M., Ellison, J., Helman, M., and Newton, J. (2010). Circular Head Coastal Foreshore Habitats: Sea Level Rise Vulnerability Assessment. Final Project Report to Cradle Coast Natural Resource Management Region. School of Geography and Environmental Studies, University of Tasmania, Hobart.

Oksanen, J., Blanchet, G., Kindt, R., Minchin, P. R., Legendre, P., O’Hara, B., Simpson, G. L., Solymos, P., Stevens, M. H. H., and Wagner, H. (2011). vegan: Community Ecology Package. R package Version 2.0-2. Available at: http://cran.rproject.org/

Platell, M. E., and Freewater, P. (2009). Importance of saltmarsh to fish species of a large south-eastern Australian estuary during a spring tide cycle. Marine and Freshwater Research 60, 936-941.

Prahalad, V. (2014). Human impacts and saltmarsh loss in the Circular Head coast, north-west Tasmania, 1952-2006: implications for management. Pacific Conservation Biology 20, 272-285.

Prahalad, V. (2016). Coastal Saltmarsh Wetland Asset Mapping: Technical Report, Cradle Coast NRM, Burnie.

Prahalad, V. N., and Kriwoken, L. K. (2010). Implementation of the Ramsar Convention on Wetlands in Tasmania, Australia. Journal of International Wildlife Law \& Policy 13, 205-239.

Prahalad, V., Sharples, C., Kirkpatrick, J., and Mount, R. (2015). Is wind-wave fetch exposure related to soft shoreline change in swell-sheltered situations with low terrestrial sediment input? Journal of Coastal Conservation 19, 23-33.

Quinn, G. P., and Keough, M. J. (2002). Experimental design and data analysis for biologists. (Cambridge University Press: Cambridge, UK.)

Raposa, K. B., and Talley, D. M. (2012). A meta-analysis of nekton responses to restoration of tide-restricted New England salt marshes. In 'Tidal Marsh Restoration'. (Eds C. T. Roman and D. M. Burdick.) pp. 97-118. (Island Press: Washington, D.C.)

Richardson, A. M. M., Swain, R., and Wong, V. (1997). The crustacean and molluscan fauna of Tasmanian saltmarshes. Papers and Proceedings of the Royal Society of Tasmania 131, 21-30. 
Roman, C. T., Raposa, K. B., Adamowicz, S. C., James-Pirri, M. J., and Catena, J. G. 677 (2002). Quantifying vegetation and nekton response to tidal restoration of a New England salt marsh. Restoration Ecology 10, 450-460.

Saintilan, N., Hossain, K., and Mazumder, D. (2007). Linkages between seagrass, Wetlands Ecology and Management 15, 277-286.

Saintilan, N., (2009). Biogeography of Australian saltmarsh plants. Austral Ecology 34, 929-937.

Svensson, C. J., Hyndes, G. A., and Lavery, P. S. (2007). Food web analysis in two permanently open temperate estuaries: Consequences of saltmarsh loss? Marine Environmental Research 64, 286-304.

Thomas, B. E., and Connolly, R. M. (2001). Fish use of subtropical saltmarshes in Queensland, Australia: relationships with vegetation, water depth and distance onto the marsh. Marine Ecology Progress Series 209, 275-288.

Valiela, I., Cole, M.I., McClelland, J., Hauxwell, J., Cebrian, J., and Joye, S.B. (2000). Role of salt marshes as part of coastal landscapes. In 'Concepts and Controversies in Tidal Marsh Ecology'. (Eds M. P. Weinstein and D. A. Kreeger.) pp. 23-38. (Kluwer: Dordrecht, the Netherlands.)

Wegscheidl, C. J., Sheaves, M., McLeod, I. M., Hedge, P. T., Gillies, C. L., and Creighton, C. (2017). Sustainable management of Australia's coastal seascapes: a case for collecting and communicating quantitative evidence to inform decisionmaking. Wetlands Ecology and Management 25, 3-22.

\section{Figures and tables}

Fig. 1. The three saltmarsh study locations and their paired unaltered and altered sites used in the Circular Head coastal area of north-west Tasmania. Base data from theLIST, (C) State of Tasmania. 


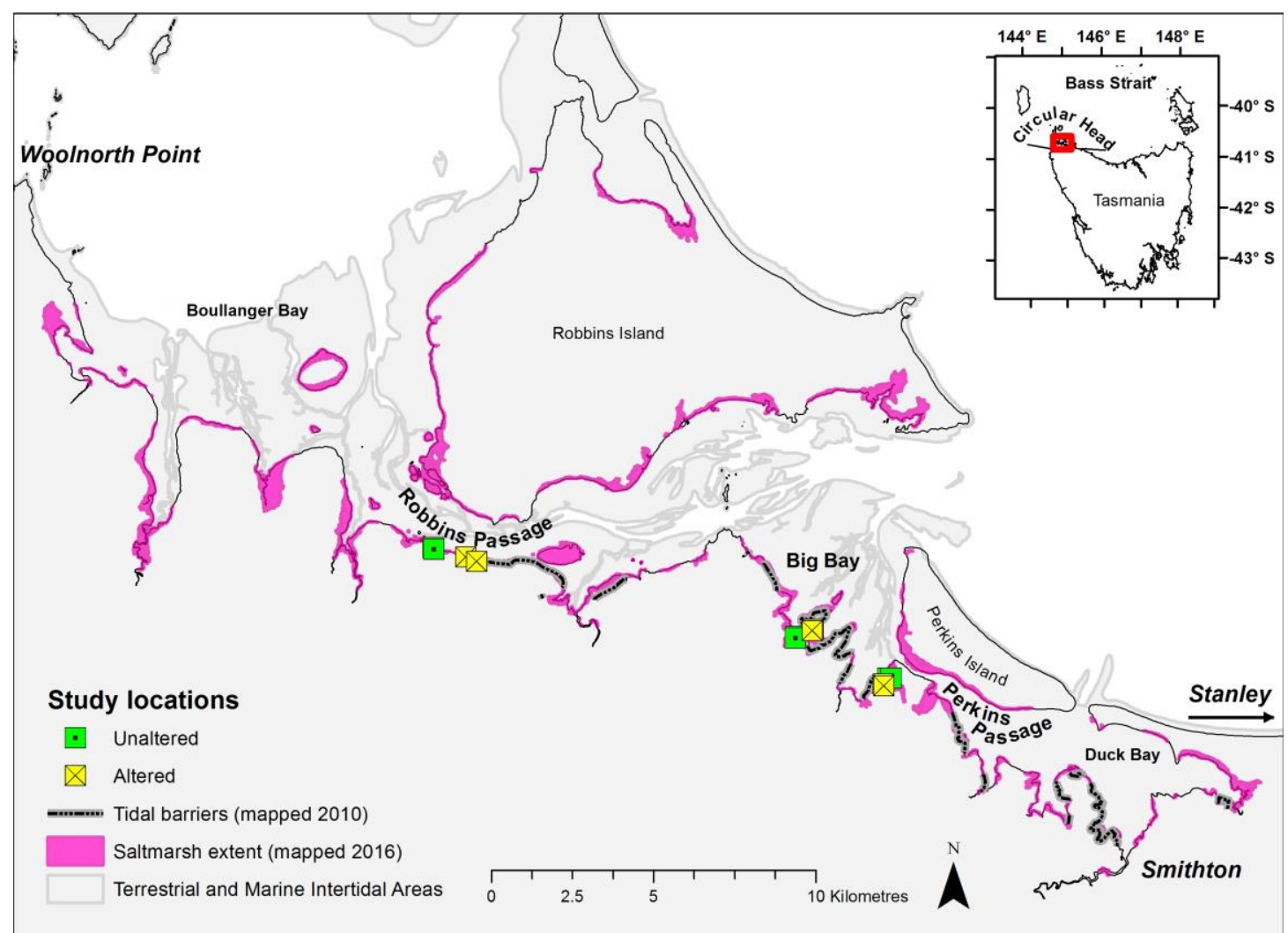

Fig. 2. Species accumulation curve (with SD) for fish species sampled on the Circular

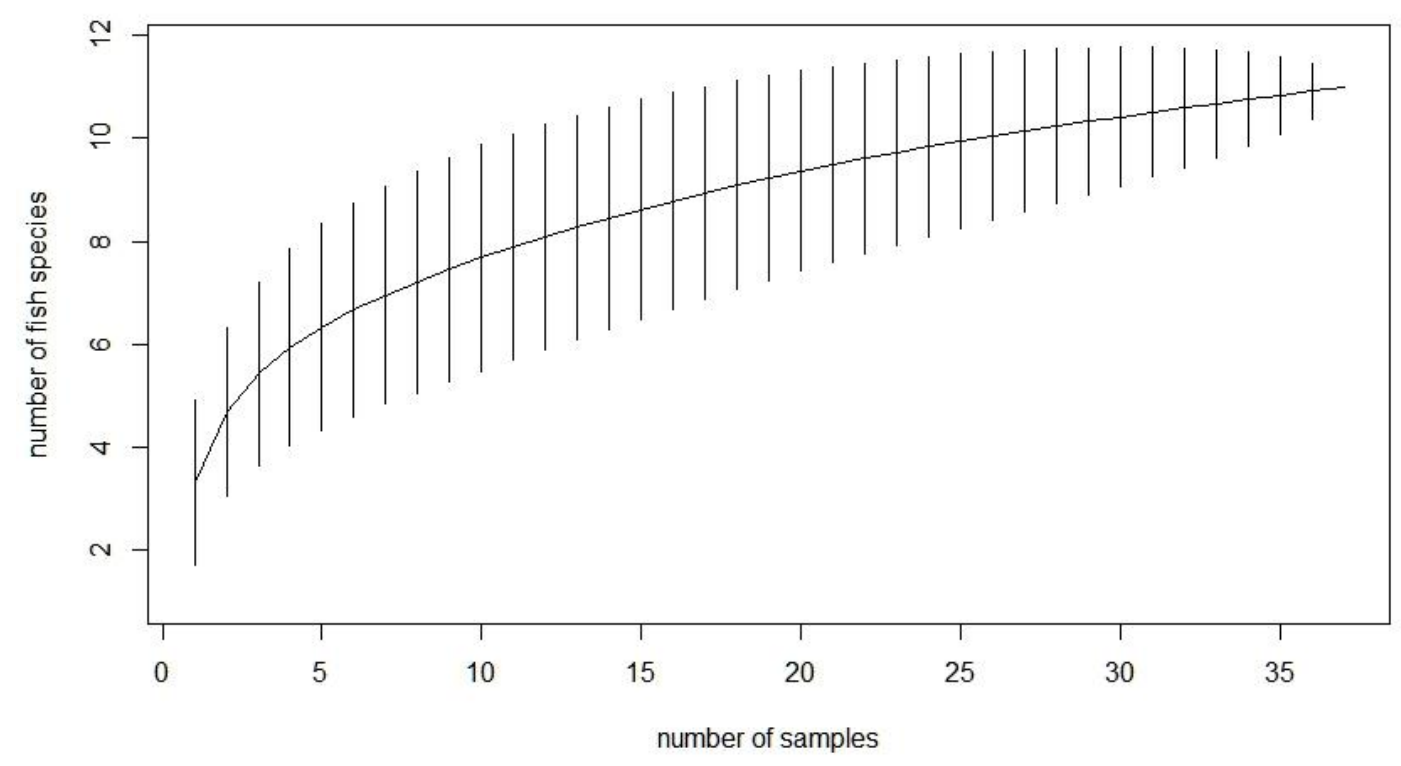


728

729 
Fig. 3. Boxplot of the fish taxa sampled from the Circular Head coast saltmarshes, north-west Tasmania. The boxes contain $50 \%$ of the observations, the median is shown by a vertical line, the circles show the range of values. Common name codes used are YEM: Yellow-eye Mullet, SMH: Smallmouth Hardyhead, SLF: Silver Fish, SF: Soldierfish, PHH: Pikehead Hardyhead, GG: Girdled Goby, GBF: Greenback Flounder, EBG: Eastern Bluespot Goby, CON: Congolli, CGA: Common Galaxias, AS: Australian Salmon.

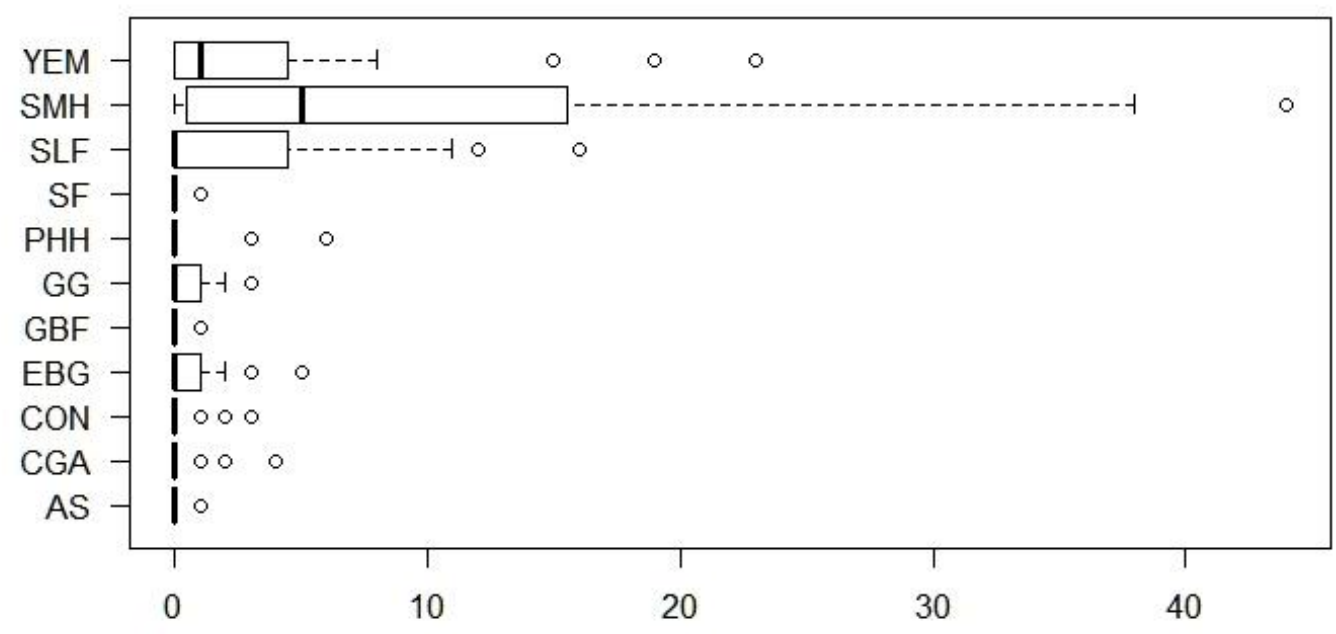

Fish per sample

Fig. 4a-b. Relationships between fish catch per sample and mean water depth: (a) neap $\left(n=19 ; r^{2}=0.763 ; p<0.001\right)$ and spring tide samples $\left(n=23 ; r^{2}=0.137 ; p=\right.$ $0.083)$; (b) altered $\left(n=22 ; r^{2}=0.265 ; \mathrm{p}<0.05\right)$ and unaltered status $\left(n=20 ; r^{2}=\right.$ 0.298; $\mathrm{p}<0.05$ ). 


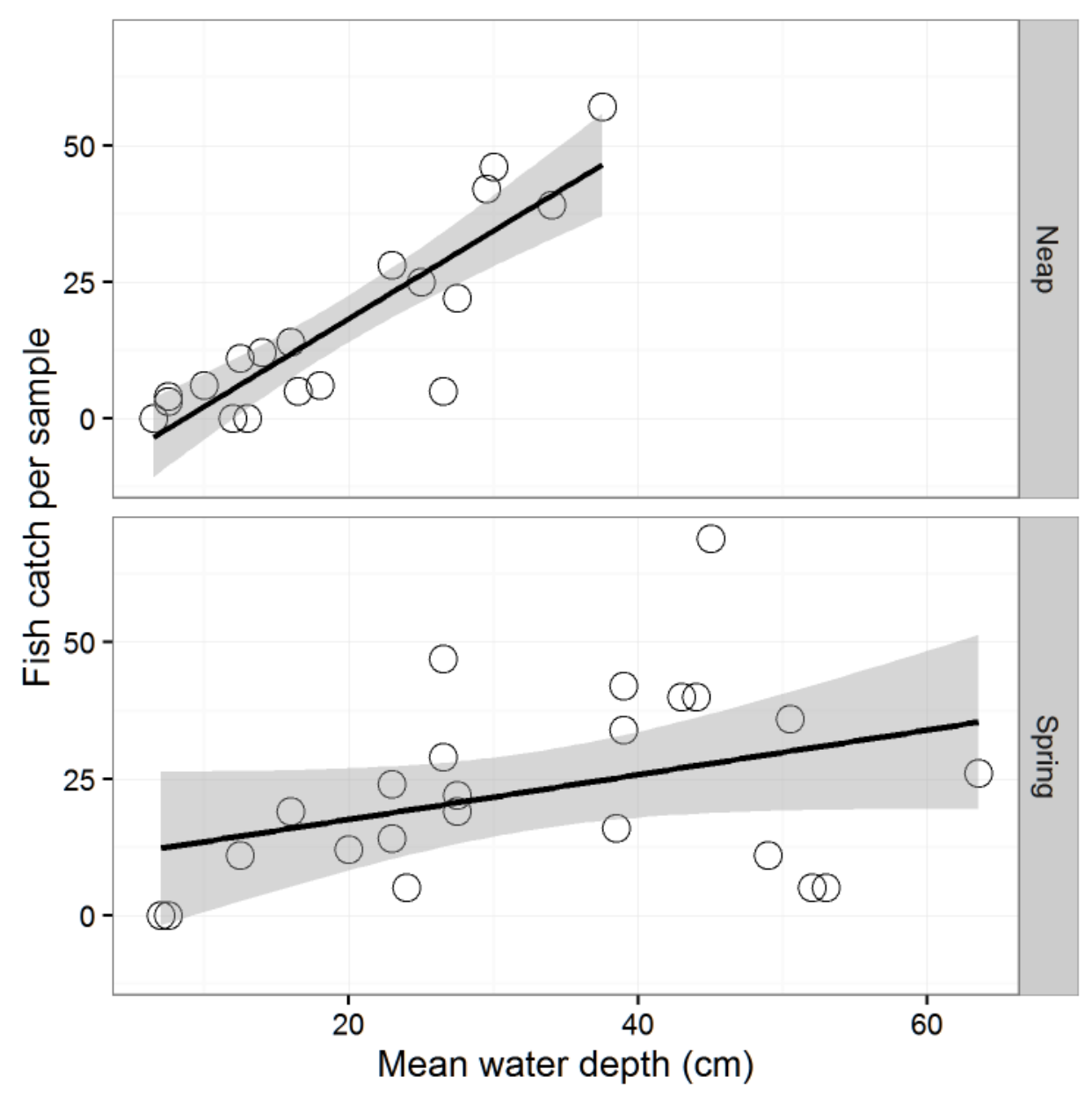



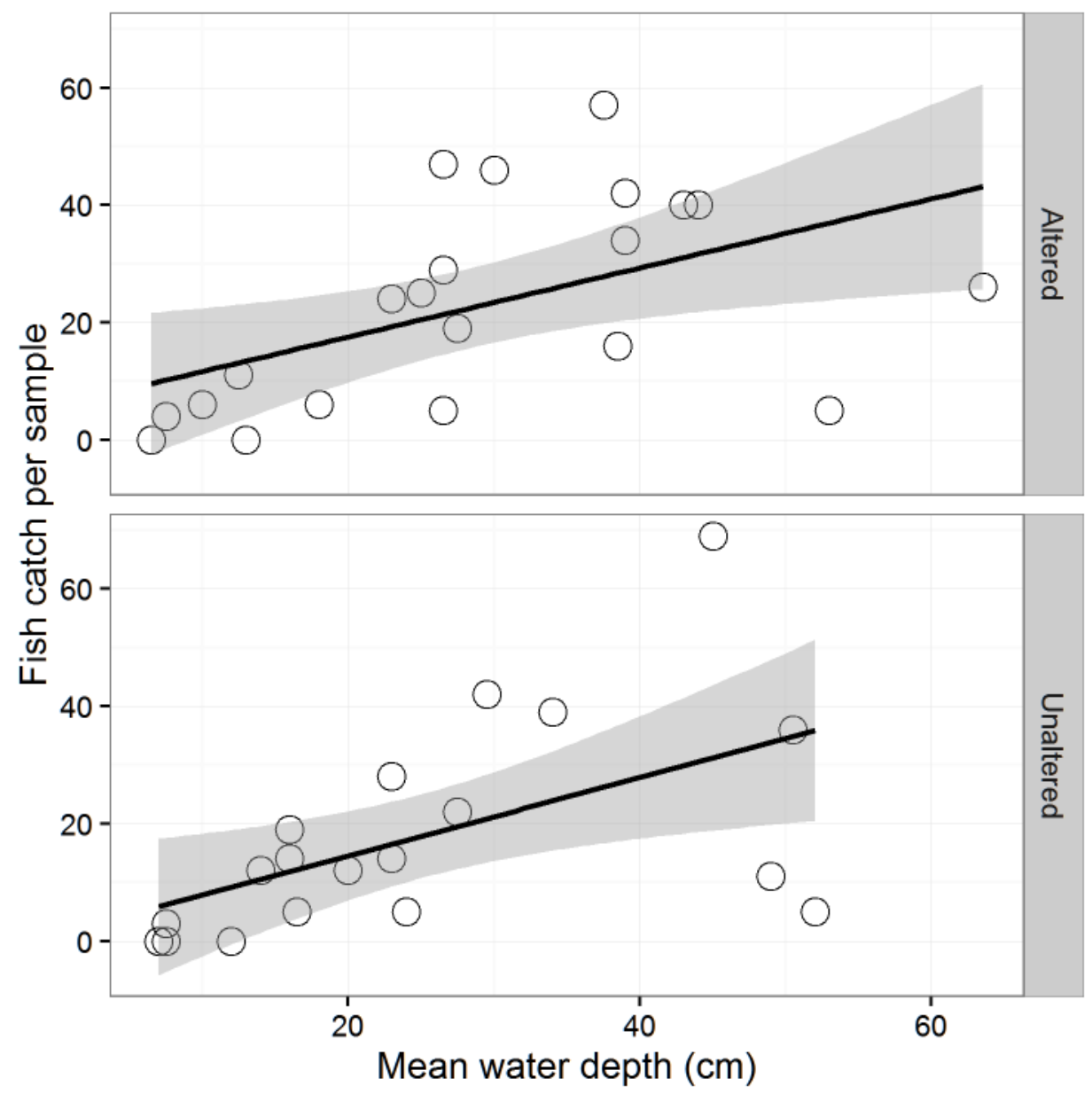

746 Fig. 5. nMDS ordination of the pop net samples based upon their fish communities from 37 of the 48 net releases which caught fish. Stress in 2D $=0.1909$. Samples from unaltered sites by closed circles, altered sites are represented by open circles. Status labels are plotted at their respective centroids. 


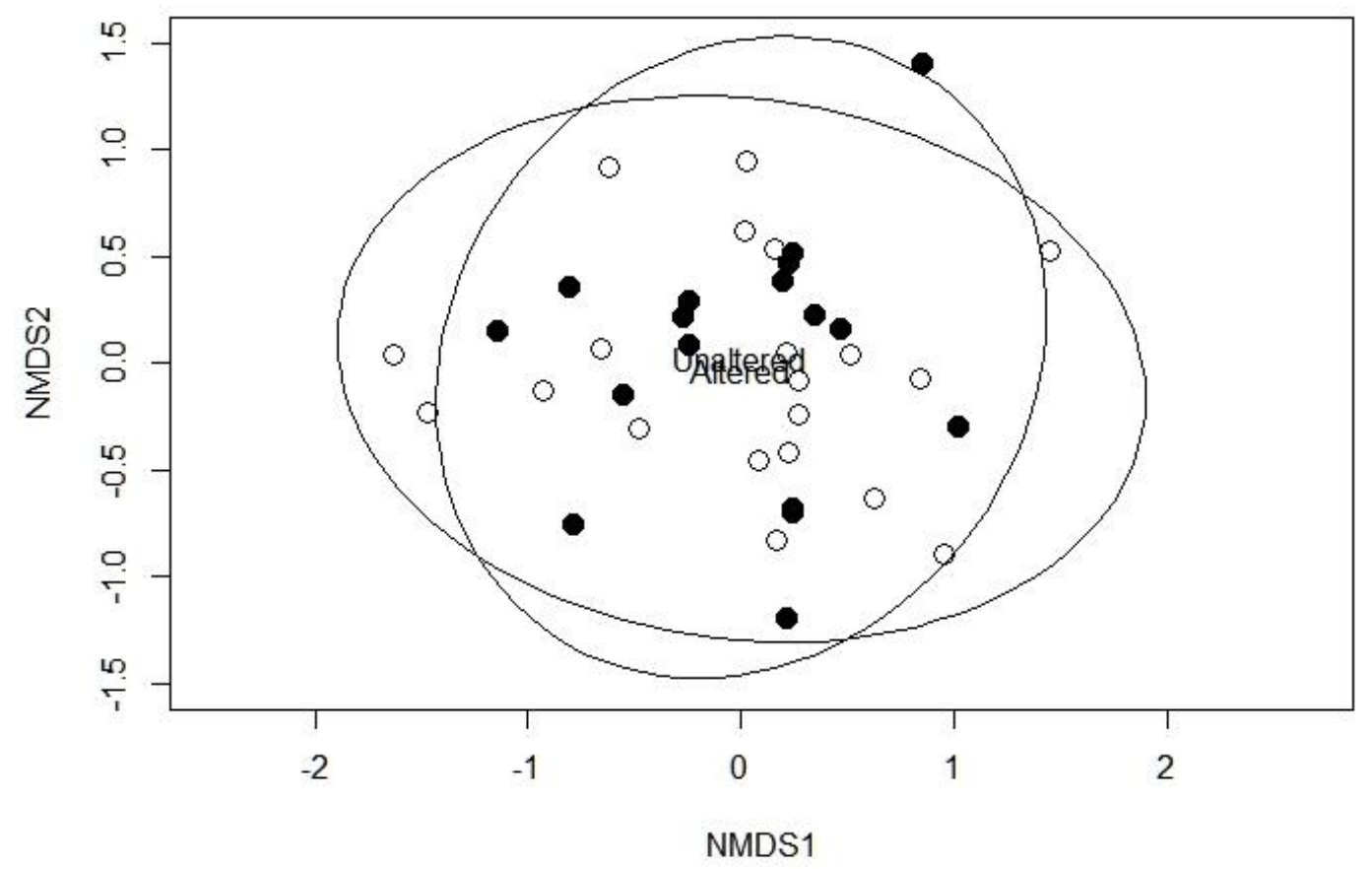

750 
Table 1 Condition of saltmarshes used in the study. Sites pairs were selected primarily based on the presence and absence of levees.

\section{Site} Condition class and variables

\begin{tabular}{llllll}
\hline Location & Class & Levees $^{1}$ & Buffer zone $^{2}$ & Saltmarsh fragmentation $^{3}$ & Saltmarsh area $^{4}$ \\
\hline Robbins Passage & Unaltered & Absent & Present & Absent & 12.1 ha \\
& Altered & Broken levees & Present but limited & Medium & 35.5 ha \\
Perkins Passage & Unaltered & Absent & Present & Medium & 13.5 ha \\
& Altered & Broken levees & Absent & High & 18.9 ha \\
\multirow{2}{*}{ Big Bay } & Unaltered & Absent & Present but limited & Medium & 15 ha \\
& Altered & Intact levees & Absent & High & 1.7 ha \\
\hline
\end{tabular}

${ }^{1}$ Broken levees are regularly breached by incoming tide.

${ }^{2}$ Buffer zone, e.g. Melaleuca ericifolia swamp forest.

${ }^{3}$ Degree of fragmentation of marsh and associated tidal creeks by levees since 1960's.

${ }^{4}$ Area of saltmarsh, contiguous but spread along the coast with a high marsh area to edge ratio.

Table 2 Fish caught using custom made buoyant floorless pop nets on saltmarsh flats on the Circular Head coast of north-west Tasmania, during April-May 2017. Species identification and naming follows Gomon et al. (2008).

\begin{tabular}{|c|c|c|c|c|c|c|c|c|c|c|c|c|c|c|c|c|}
\hline \multirow[t]{4}{*}{ Family } & \multirow[t]{4}{*}{ Genus/species } & \multirow[t]{4}{*}{$\begin{array}{l}\text { Common } \\
\text { name }\end{array}$} & \multicolumn{14}{|c|}{ Contribution to catch } \\
\hline & & & \multicolumn{4}{|c|}{ Robbins Passage } & \multicolumn{4}{|c|}{ Perkins Passage } & \multicolumn{4}{|c|}{ Big Bay } & \multicolumn{2}{|l|}{ Total } \\
\hline & & & \multicolumn{2}{|c|}{ Unaltered } & \multicolumn{2}{|c|}{ Altered } & \multicolumn{2}{|c|}{ Unaltered } & \multicolumn{2}{|c|}{ Altered } & \multicolumn{2}{|c|}{ Unaltered } & \multicolumn{2}{|l|}{ Altered } & & \\
\hline & & & Total & $\%$ & Total & $\%$ & Total & $\%$ & Total & $\%$ & Total & $\%$ & Total & $\%$ & Total & $\%$ \\
\hline \multirow[t]{3}{*}{ Atherinidae } & $\begin{array}{l}\text { Atherinosoma microstoma } \\
\text { (Günther, 1861) } \\
\text { Kestratherina esox }\end{array}$ & $\begin{array}{l}\text { Smallmouth } \\
\text { Hardyhead } \\
\text { Pikehead }\end{array}$ & 37 & 55.2 & 129 & 64.2 & 21 & 34.4 & 47 & 34.8 & 146 & 63.5 & 102 & 65.0 & 482 & 56.6 \\
\hline & $\begin{array}{l}\text { (Klunzinger, 1872) } \\
\text { Leptatherina presbyteroides }\end{array}$ & Hardyhead & 0 & 0 & 3 & 1.5 & 3 & 4.9 & 0 & 0 & 0 & 0 & 6 & 3.8 & 12 & 1.4 \\
\hline & (Richardson, 1843) & Silver Fish & 7 & 10.4 & 50 & 24.9 & 6 & 9.8 & 15 & 11.1 & 39 & 17.0 & 18 & 11.5 & 135 & 15.9 \\
\hline
\end{tabular}




\begin{tabular}{|c|c|c|c|c|c|c|c|c|c|c|c|c|c|c|c|c|}
\hline Gobiidae & $\begin{array}{l}\text { Nesogobius maccullochi } \\
\text { (Hoese and Larson, 2006) }\end{array}$ & $\begin{array}{l}\text { Girdled } \\
\text { Goby } \\
\text { Eastern } \\
\text { Bluespot }\end{array}$ & 2 & 3.0 & 2 & 1.0 & 2 & 3.3 & 7 & 5.2 & 5 & 2.2 & 0 & 0 & 18 & 2.1 \\
\hline & Pseudogobius sp. & Goby & 10 & 14.9 & 7 & 3.5 & 1 & 1.6 & 4 & 3.0 & 0 & 0 & 6 & 3.8 & 28 & 3.3 \\
\hline Mugilidae & $\begin{array}{l}\text { Aldrichetta forsteri } \\
\text { (Valenciennes, 1836) }\end{array}$ & $\begin{array}{l}\text { Yellow-eye } \\
\text { Mullet* }\end{array}$ & 10 & 14.9 & 10 & 5.0 & 27 & 44.3 & 50 & 37.0 & 40 & 17.4 & 23 & 14.6 & 160 & 18.8 \\
\hline Pleuronectidae & $\begin{array}{l}\text { Rhombosolea tapirina } \\
\text { (Günther, 1862) }\end{array}$ & $\begin{array}{l}\text { Greenback } \\
\text { Flounder* }\end{array}$ & 0 & 0 & 0 & 0 & 0 & 0 & 1 & 0.7 & 0 & 0 & 0 & 0 & 1 & 0.1 \\
\hline Pseudaphritidae & $\begin{array}{l}\text { Pseudaphritis urvillii } \\
\text { (Valenciennes, 1832) }\end{array}$ & Congolli & 0 & 0 & 0 & 0 & 0 & 0 & 5 & 3.7 & 0 & 0 & 1 & 0.6 & 6 & 0.7 \\
\hline Tetrarogidae & $\begin{array}{l}\text { Gymnapistes marmoratus } \\
\text { (Cuvier, 1829) }\end{array}$ & Soldierfish & 0 & 0 & 0 & 0 & 0 & 0 & 0 & 0 & 0 & 0 & 1 & 0.6 & 1 & 0.1 \\
\hline Arripidae & $\begin{array}{l}\text { Arripis truttaceus (Cuvier, } \\
\text { 1829) }\end{array}$ & $\begin{array}{l}\text { Australian } \\
\text { Salmon* }\end{array}$ & 1 & 1.5 & 0 & 0 & 0 & 0 & 0 & 0 & 0 & 0 & 0 & 0 & 1 & 0.1 \\
\hline Galaxiidae & $\begin{array}{l}\text { Galaxias maculatus } \\
\text { (Jenyns, 1842) }\end{array}$ & $\begin{array}{l}\text { Common } \\
\text { Galaxias }\end{array}$ & 0 & 0 & 0 & 0 & 1 & 1.6 & 6 & 4.4 & 0 & 0 & 0 & 0 & 7 & 0.8 \\
\hline \multicolumn{3}{|c|}{ Total catch per sample type } & 67 & & 201 & & 61 & & 135 & & 230 & & 157 & & 851 & \\
\hline \multicolumn{3}{|c|}{$\begin{array}{l}\text { Fish density per } 100 \mathrm{~m}^{-2} \\
\text { Fish density per } 100 \mathrm{~m}^{-2} \text { (excluding nets with less than } 5 \mathrm{~cm} \\
\text { water depth) }\end{array}$} & 38.3 & & 100.5 & & 30.5 & & 67.5 & & 115 & & 78.5 & & 72.4 & \\
\hline
\end{tabular}

The asterisk (*) indicates species of recreational and commercial interest (Lyle et al. 2014). 
Table 3. Coefficients for GLMs relating fish species richness, catch and the abundance of the two most common fish species to environmental variables. Values have not been exponentiated. The model for species richness uses Poisson regression, the other response variables follow a quasi-Poisson distribution. WDmean $=$ mean water depth. Significance levels are indicated as: $* * * \mathrm{p}<0.001, * * \mathrm{p}<0.01, * \mathrm{p}<0.05, . \mathrm{p}<0.10$.

\begin{tabular}{|c|c|c|c|c|c|}
\hline & Estimate & $\mathbf{S E}$ & t value & $\operatorname{Pr}(>|\mathbf{t}|)$ & signif. \\
\hline \multicolumn{6}{|l|}{ Species Richness } \\
\hline (Intercept) & -1.7124 & 8.7227 & -0.196 & 0.8444 & \\
\hline Location: Perkins Passage & 0.0653 & 0.3400 & 0.192 & 0.8476 & \\
\hline Location: Robbins Passage & 0.0750 & 0.3618 & 0.207 & 0.8357 & \\
\hline Status: Unaltered & -0.0613 & 0.1858 & -0.330 & 0.7415 & \\
\hline Tide: Spring & -0.0782 & 0.4972 & -0.157 & 0.8751 & \\
\hline Phase: Light & -0.6144 & 0.2487 & -2.471 & 0.0135 & $*$ \\
\hline Salinity & 0.0660 & 0.2369 & 0.279 & 0.7806 & \\
\hline WDmean & 0.0204 & 0.0077 & 2.639 & 0.0083 & $* *$ \\
\hline \multicolumn{6}{|l|}{ Catch Numbers } \\
\hline (Intercept) & -7.5104 & 7.9607 & -0.943 & 0.3510 & \\
\hline Location: Perkins Passage & 0.0757 & 0.3289 & 0.230 & 0.8190 & \\
\hline Location: Robbins Passage & 0.1768 & 0.3317 & 0.533 & 0.5970 & \\
\hline Status: Unaltered & -0.1332 & 0.1735 & -0.768 & 0.4470 & \\
\hline Tide: Spring & 0.0933 & 0.4700 & 0.198 & 0.8440 & \\
\hline Phase: Light & -1.4914 & 0.2993 & -4.983 & 0.0000 & $* * *$ \\
\hline Salinity & 0.2643 & 0.2158 & 1.225 & 0.2280 & \\
\hline WDmean & 0.0458 & 0.0080 & 5.719 & 0.0000 & $* * *$ \\
\hline \multicolumn{6}{|l|}{ Smallmouth Hardyhead } \\
\hline (Intercept) & -5.5752 & 9.0677 & -0.615 & 0.5420 & \\
\hline Location: Perkins Passage & -0.5936 & 0.4059 & -1.462 & 0.1520 & \\
\hline
\end{tabular}




\begin{tabular}{lccccc} 
Location: Robbins Passage & -0.0056 & 0.3742 & -0.015 & 0.9880 & \\
Status: Unaltered & -0.1959 & 0.2030 & -0.965 & 0.3410 & \\
Tide: Spring & -0.2365 & 0.5553 & -0.426 & 0.6730 & \\
Phase: Light & -1.5162 & 0.3424 & -4.429 & 0.0001 & $* * *$ \\
Salinity & 0.1989 & 0.2461 & 0.808 & 0.4240 & \\
WDmean & 0.0521 & 0.0097 & 5.395 & 0.0000 & $* * *$ \\
Yellow-eye Mullet & & & & & \\
(Intercept) & -10.0165 & 18.8957 & -0.530 & 0.5991 & \\
Location: Perkins Passage & 1.4328 & 0.7216 & 1.985 & 0.0542 &. \\
Location: Robbins Passage & 0.1393 & 0.9812 & 0.142 & 0.8878 & \\
Status: Unaltered & 0.3963 & 0.3192 & 1.242 & 0.2218 & \\
Tide: Spring & 1.1728 & 0.9923 & 1.182 & 0.2444 & \\
Phase: Light & -3.5222 & 1.3271 & -2.654 & 0.0114 & $*$ \\
Salinity & 0.2367 & 0.5092 & 0.465 & 0.6446 & \\
WDmean & 0.0576 & 0.0146 & 3.946 & 0.0003 & $* * *$ \\
\hline
\end{tabular}

Table 4. Compilation of fish data and key study design attributes from existing literature that report using pop nets on saltmarsh flats in Australia (cf. Connolly 2009; Wegscheidl et al. 2017). Given all previous pop nets studies have been done only during spring tides, we report our spring tide samples separately to assist comparison.

\begin{tabular}{|c|c|c|c|c|c|c|c|c|c|c|}
\hline Region & State & Reference & $\begin{array}{l}\text { No of } \\
\text { releases }\end{array}$ & $\begin{array}{l}\text { Fish } \\
\text { caught in } \\
\text { total } \\
\text { numbers } \\
\end{array}$ & $\begin{array}{l}\text { Diversity } \\
\text { (number } \\
\text { of } \\
\text { species) }\end{array}$ & 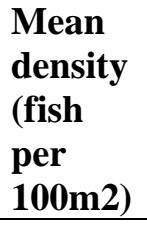 & $\begin{array}{l}\text { Pop net } \\
\text { size } \\
(\mathrm{m} 2)\end{array}$ & $\begin{array}{l}\text { Temporal } \\
\text { context } \\
\text { (sampling } \\
\text { month) } \\
\end{array}$ & $\begin{array}{l}\text { Spatial context } \\
\text { (with } \\
\text { mangroves etc.) }\end{array}$ & $\begin{array}{l}\text { Mean water } \\
\text { depth } \\
\text { (proxy for } \\
\text { volume) }\end{array}$ \\
\hline \multirow[t]{2}{*}{ Subtropical } & QLD & $\begin{array}{l}\text { Thomas and } \\
\text { Connolly } 2001\end{array}$ & 134 & 577 & 23 & 17.2 & $5 \times 5$ & $\begin{array}{l}\text { August, } \\
\text { January }\end{array}$ & Flats & $4-72 \mathrm{~cm}$ \\
\hline & & Connolly 2005 & 88 & 1073 & 19 & 48.8 & $5 \times 5$ & May, & Flats, adjacent & $6-48 \mathrm{~cm}$ \\
\hline
\end{tabular}




\begin{tabular}{|c|c|c|c|c|c|c|c|c|c|c|}
\hline & & & & & & & & December & $\begin{array}{l}\text { runnels and } \\
\text { mangrove-lined } \\
\text { creeks }\end{array}$ & \\
\hline \multirow[t]{8}{*}{ Temperate } & NSW & $\begin{array}{l}\text { Mazumder et al. } \\
\text { 2005a }\end{array}$ & 48 & 818 & 14 & 56 & $5.5 \times 5.5$ & $\begin{array}{l}\text { Year round } \\
\text { (monthly) }\end{array}$ & $\begin{array}{l}\text { Flats, adjacent } \\
\text { mangroves }\end{array}$ & Not reported \\
\hline & & $\begin{array}{l}\text { Mazumder et al. } \\
\text { 2005b }\end{array}$ & 48 & 766 & 15 & 52.8 & $5.5 \times 5.5$ & $\begin{array}{l}\text { Year round } \\
\text { (monthly) }\end{array}$ & $\begin{array}{l}\text { Flats, adjacent } \\
\text { mangroves } \\
\text { Flats, adjacent }\end{array}$ & Not reported \\
\hline & & Saintilan et al. 2007 & 36 & $\sim 568$ & 14 & 52.2 & $5.5 \times 5.5$ & $\begin{array}{l}\text { Year round } \\
\text { (monthly) }\end{array}$ & $\begin{array}{l}\text { mangroves and } \\
\text { seagrass } \\
\text { Flats with }\end{array}$ & Not reported \\
\hline & SA & Connolly et al. 1997 & 48 & 19 & 2 & 4.4 & $3 \times 3$ & $\begin{array}{l}\text { April-July } \\
\text { July, August. }\end{array}$ & $\begin{array}{l}\text { creeks, adjacent } \\
\text { mangroves and } \\
\text { seagrass }\end{array}$ & $10-30 \mathrm{~cm}$ \\
\hline & & $\begin{array}{l}\text { Bloomfield and } \\
\text { Gillanders } 2005\end{array}$ & 30 & 1 & 1 & 0.4 & $3 \times 3$ & $\begin{array}{l}\text { December- } \\
\text { February }\end{array}$ & $\begin{array}{l}\text { mangroves and } \\
\text { seagrass }\end{array}$ & $>70 \mathrm{~cm}$ \\
\hline & TAS & Present study & 48 & 851 & 11 & 72.4 & $5 \times 5$ & April, May & Flats & $0-64 \mathrm{~cm}$ \\
\hline & TAS & $\begin{array}{l}\text { Present study (neap } \\
\text { tide only) } \\
\text { Present study (spring }\end{array}$ & 24 & 325 & 9 & 56.5 & $5 \times 5$ & April & Flats & $0-38 \mathrm{~cm}$ \\
\hline & TAS & tide only) & 24 & 526 & 9 & 87.7 & $5 \times 5$ & May & Flats & $2-64 \mathrm{~cm}$ \\
\hline
\end{tabular}

